\title{
Improvement of Black Cotton Soil Properties Using E-waste
}

\author{
Mangesh Chaugule ${ }^{1}$, Shantanu Deore ${ }^{1}$, Karan Gawade ${ }^{1}$, Ambaresh Tijare ${ }^{1}$, \\ Shailendra Banne ${ }^{2}$ \\ ${ }^{1}$ (Student, Department of Civil Engineering, Pimpri Chinchawad College of Engineering, Pune-411044, India) \\ ${ }^{2}$ (Assistant Professor, Department of Civil Engineering, Pimpri Chinchawad College of Engineering,Pune- \\ 411044, India)
}

\begin{abstract}
Soil Stabilization is the phenomenon which deals with modifying the properties of soil (Index \& Engineering) to improve its performance. Stabilization is being used for a variety of engineering works either in its natural form or in a processed form. Eventually all structures rest on soil foundation where the main objective is to increase the strength or stability of soil and to reduce the construction cost. Now a day the utilization of waste products with soil has gained attention due to the increasing problems of waste management. This paper presents the results of an experimental program undertaken to investigate the effect of $E$-waste at different dosages on black cotton soil. Different dosages of E-waste i.e. $2 \%, 5 \%$ and $8 \%$ were added in the soil. The performance of E-waste stabilized soil was evaluated using physical and strength performance tests namely; Atterberg's limit, specific gravity, compaction test, unconfined compressive test, California bearing ratio $(C B R)$ and direct shear test. Theses test were conducted in order to evaluate the improvement in the strength characteristics of the soil. From the results, unconfined compressive strength of specimen increased with an average of $2.41 \mathrm{kN} / \mathrm{m}^{2}$ for fixed dosage of E-waste. After performing direct shear test, there was an improvement in angle of friction $(\Phi)$. As the percentage of $E$-waste increased, $\Phi$ increased. As bearing capacity is dependent on $C$ and $\Phi$, it was also observed that there is an increase in bearing capacity of the soil.
\end{abstract}

Keywords: E-waste, Black cotton soil, Soil stabilization, direct Shear Test.

\section{Introduction}

Clayey soil expands when they are wetted and shrink when dried. These soils are called as expansive soil or swelling soil. Due to swelling nature, the BCS is problematic for construction. It swells and shrinks excessively with the change of water content due to presence of fine clay particles which swell, when they come in contact with water, resulting in alternate swelling and shrinking of soil due to which differential settlement of structure takes place. The BCS cover the plateaus of Maharashtra, Saurashtra, Malwa, Madhya Pradesh, Chhattisgarh and extend in South-East direction along Godavari and Krishna valleys in India (approximately $300,000 \mathrm{~km}^{2}$ ).

In the 20th Century, the information and communication revolution has brought enormous changes in the way we organize our lives, our economies, industries and institutions. These spectacular developments in modern times have undoubtedly enhanced the quality of our lives. At the same time, these have led to manifold problems including the problem of massive amount of hazardous waste and other wastes generated from electric products thus increasing the amount of E-waste day by day. E-Waste in turn deals with the disposal techniques. Recycling is one of the disposal techniques, but if it is not recycled then it has to be land filled in a nearby disposal facility. So by taking this point in consideration we have adopted 'The Use of E-Waste', for improving the stability of the soils.

In construction of any structure engineering properties of soils is the important factor to be considered. As soil also has a relation with water and thus stabilizing the soil will increase the rate of tolerance of water into the soil thus making it quite ideal for engineering purpose. Soil stabilization may increase the volume of soil which will result in less consolidation. Thus, after addition of E-waste improvement in the soil properties can be seen which results in soil stabilization.

\subsection{Objectives of the Study}

i. To investigate the effect of $\mathrm{E}$ waste on shear strength parameters on soil.

ii. To improve the CBR value of the soil.

iii. To investigate the effect of E-waste on OMC and MDD.

iv. To increase bearing capacity of soil. 


\subsection{Black Cotton Soil}

\section{Materials Used For Study}

The materials used for the tests include the black cotton soil and E-waste. The soil was procured from Ravet, Pune District. Manual labour was used for the procurement of soil. Bigger size lumps were broken down with rammers. Then it was oven dried for 24 hours at $105^{\circ}$ to $110^{\circ} \mathrm{C}$.

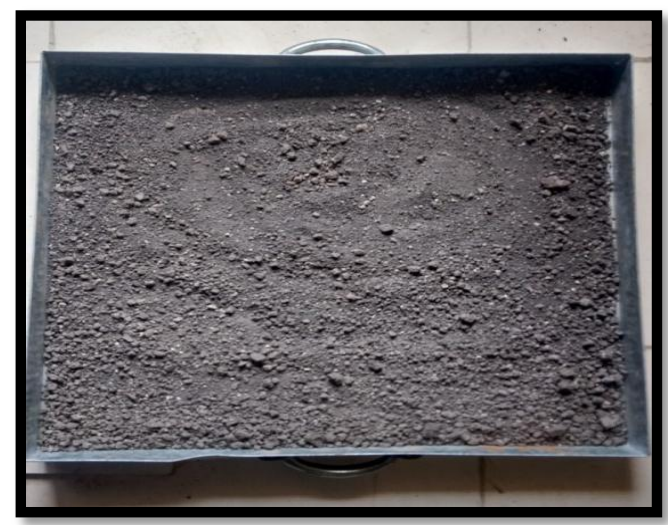

Fig. 1: Black Cotton Soil

\subsection{E-waste}

Electronic waste may be described as the discarded electronic equipments such as mobile phones, computers, household appliances which fail or are no more fit for its originally intended use. Everyday advancements in technology have resulted in fast growing surplus of electronic waste around the globe. Around 50 million tons of E-waste is generated annually around the globe. Developing countries like India are being used to dump large masses of E-waste without its sorting or dismantling.

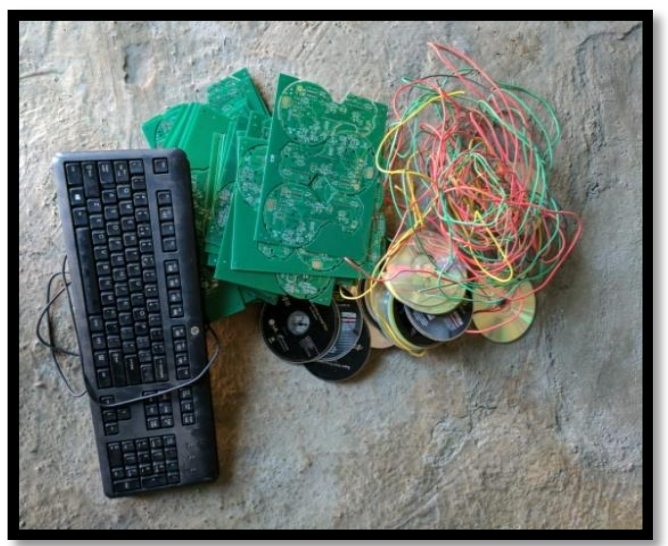

Fig. 2: E-waste before grinding

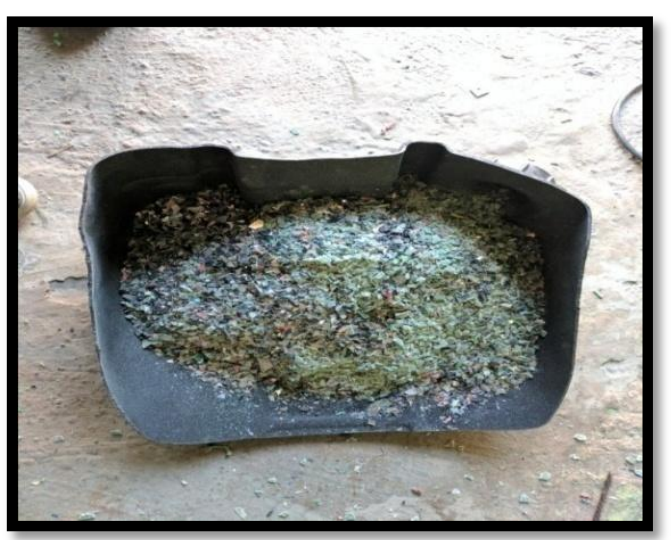

Fig. 3: E-waste after grinding

\section{Methodology}

Laboratory tests were conducted on black cotton soil with and without E-waste. In order to evaluate the improvement in strength properties, physical and strength performance tests namely; Atterberg's Limit, Specific Gravity, Compaction Test, Unconfined Compressive Test, California Bearing Ratio (CBR) and Direct Shear Test were performed.

\section{Properties Of Black Cotton Soil}

Table 1- Properties of Black Cotton Soil

\begin{tabular}{|c|c|c|}
\hline Sr. No. & PROPERTY & VALUE \\
\hline 1. & Dry Density $\left(\mathrm{V}_{\mathrm{d}}\right)$ & $13.5 \mathrm{kN} / \mathrm{m}^{3}$ \\
\hline 2. & $\begin{array}{l}\text { Grain Size Distribution (IS 2720: Part 4) } \\
\text { a) Gravel } \\
\text { b) Sand } \\
\text { c) }\end{array}$ & $\begin{array}{l}0.56 \% \\
13.44 \% \\
86 \%\end{array}$ \\
\hline 3. & Liquid Limit $\left(\mathrm{W}_{\mathrm{L}}\right)$ (IS 2720: Part 5) & $80.3 \%$ \\
\hline 4. & Plastic Limit (W) (IS 2720: Part 5) & $61.5 \%$ \\
\hline 5. & Plasticity Index (I $\mathrm{I}_{\mathrm{P}}$ (IS 2720: Part 5) & $18.8 \%$ \\
\hline 6. & IS classification of soil & $\mathrm{CH}$ or $\mathrm{MH}$ \\
\hline
\end{tabular}


Improvement of Black Cotton Soil Properties using E-waste

\begin{tabular}{|l|l|l|}
\hline 7. & Specific Gravity & 2.38 \\
\hline 8. & $\begin{array}{r}\text { Compaction (IS 2720: Part 8) } \\
\text { a) Maximum Dry Density }\end{array}$ & $15 \mathrm{kN} / \mathrm{m}^{3}$ \\
& b) Optimum Water Content & $25 \%$ \\
\hline 9. & $\begin{array}{r}\text { Direct Shear Test (IS 2720: Part 13) } \\
\text { a) Cohesion (C) }\end{array}$ & $47 \mathrm{kN} / \mathrm{m}^{2}$ \\
& b) Angle of Friction (Ф) & $9.09^{\circ}$ \\
\hline 10. & Unconfined compressive strength (IS 2720: Part 10) & $11.03 \mathrm{kN} / \mathrm{m}^{2}$ \\
\hline 11. & California Bearing Ratio CBR (IS 2720: Part 16) & $19.65 \%$ \\
\hline 12. & Unsoaked & $73.68 \%$ \\
\hline
\end{tabular}

\section{Results And Discussion}

After the determination of basic properties of black cotton soil, soil stabilized with E-waste and the strength parameters like $\mathrm{C} \& \Phi$, MDD and OMC, CBR and UCS were determined by conducting direct shear, compaction , CBR (California bearing ratio) and UCS (unconfined compressive stress) tests. Following are the results obtained after performing tests.

\subsection{Sieve Analysis of E-waste}

For grain size distribution of E-waste, sieve analysis test have been performed. The coefficient of uniformity and curvature are determined from figure1. The determined value for

i. Coefficient of Uniformity $\left(\mathrm{C}_{\mathrm{u}}\right)=4$

ii. Coefficient of Curvature $\left(\mathrm{C}_{\mathrm{c}}\right)=2.1$

As per IS 2720: Part 4, as the values of $C_{u}$ and $C_{c}$ are 4 and 2.1 respectively the E-waste is well-graded

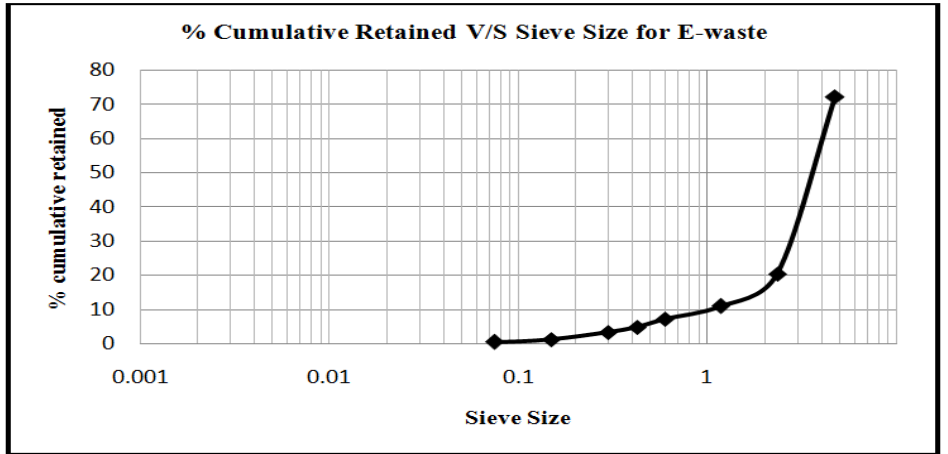

Fig 4: Sieve analysis of E-waste

\subsection{Atterberg's Limit}

These are the basic measure of the critical water contents of soil i.e. its liquid limit, plastic limit and shrinkage limit. After performing tests for liquid and plastic limit with and without addition of E-waste; soil undergoes distinct changes in behavior and consistency. Following are the results tabulated for liquid limit, plastic limit and plasticity index.

Table 2: Atterberg's Limit

\begin{tabular}{|c|c|c|c|c|}
\hline Sr. No. & SAMPLE & $\mathbf{W}_{\mathbf{L}}(\boldsymbol{\%})$ & $\mathbf{W}_{\mathbf{P}}(\boldsymbol{\%})$ & $\mathbf{I}_{\mathbf{P}}(\boldsymbol{\%})$ \\
\hline 1. & Black Cotton Soil & 80.30 & 61.50 & 18.80 \\
\hline 2. & Black Cotton Soil + 2\% E-waste & 83.30 & 60.00 & 23.30 \\
\hline 3. & Black Cotton Soil + 5\% E-waste & 85.00 & 82.63 & 2.37 \\
\hline 4. & Black Cotton Soil + 8\% E-waste & 82.60 & 74.40 & 8.20 \\
\hline
\end{tabular}

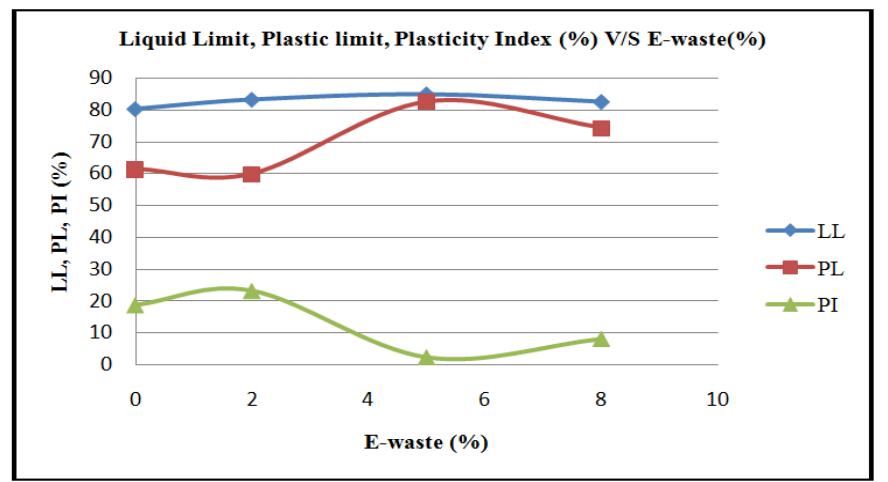

Fig. 5: Variation in LL, PL and PI with increase in E-waste 


\subsection{Standard Proctor Test}

Compaction test were performed for all the specimens i.e. with and without E-waste. Following are the results tabulated in table 3 which shows OMC and MDD for respective specimens.

Table No 3: MDD and OMC

\begin{tabular}{|c|c|c|c|}
\hline Sr. No. & SAMPLE & OMC (\%) & MDD $\left(\mathbf{k g} / \mathbf{m}^{\mathbf{3}}\right)$ \\
\hline 1. & Black Cotton Soil & 25 & 1.5 \\
\hline 2. & Black Cotton Soil + 2\% E-waste & 22.5 & 1.56 \\
\hline 3. & Black Cotton Soil + 5\% E-waste & 13.5 & 1.57 \\
\hline 4. & Black Cotton Soil + 8\% E-waste & 30.6 & 1.46 \\
\hline
\end{tabular}

The variation in OMC and MDD can be figured out from the figure 6. OMC and MDD curves are plotted for each specimen.

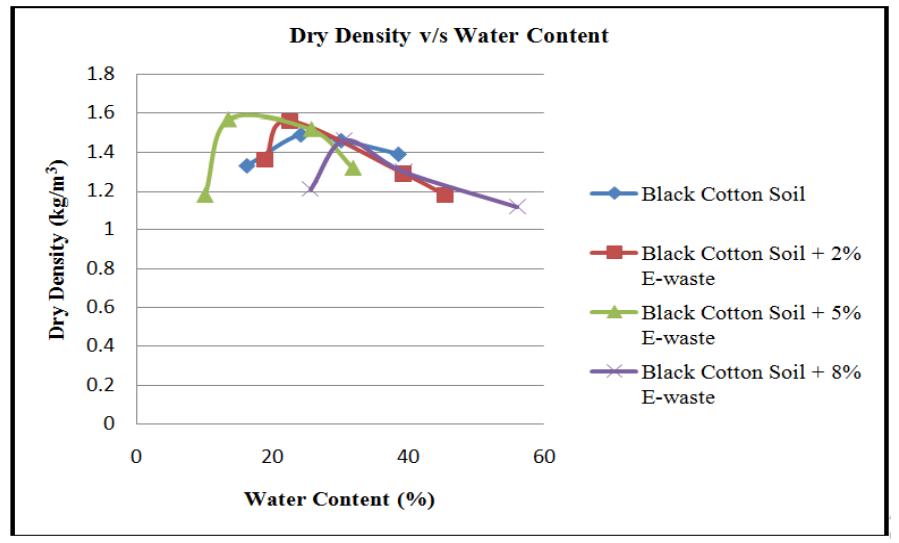

Fig. 6: Variation in compaction curves with addition of E-waste.

As the addition of E-waste increases, MDD increases and OMC decreases. For $8 \%$ dosage of E-waste MDD decreased and $\mathrm{OMC}$ increased. Following figure 7 shows the direct relationship between MDD and E-waste.

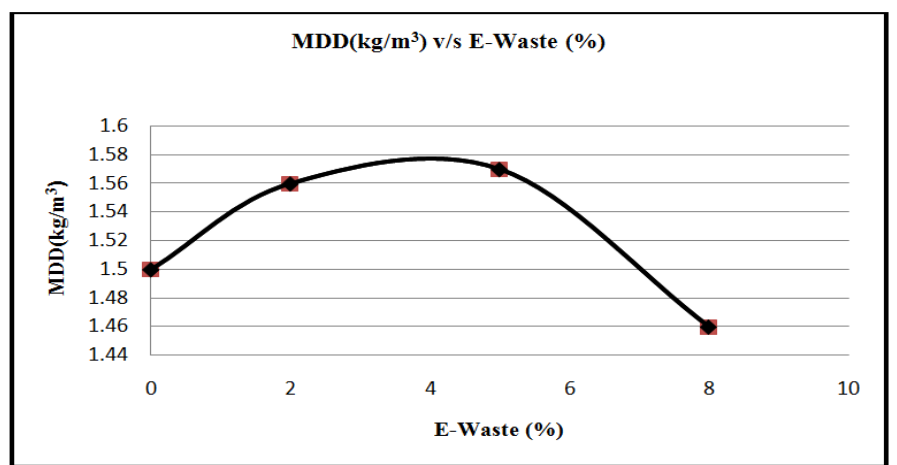

Fig 7: Variation of maximum dry density with addition of E-waste.

\subsection{Unconfined Compression Test}

In this test, the cylindrical specimen is loaded axially by a compressive force until the failure takes place. The value of UCS increases with addition of E-waste. Fig 8 shows direct relation between UCS and E-waste.

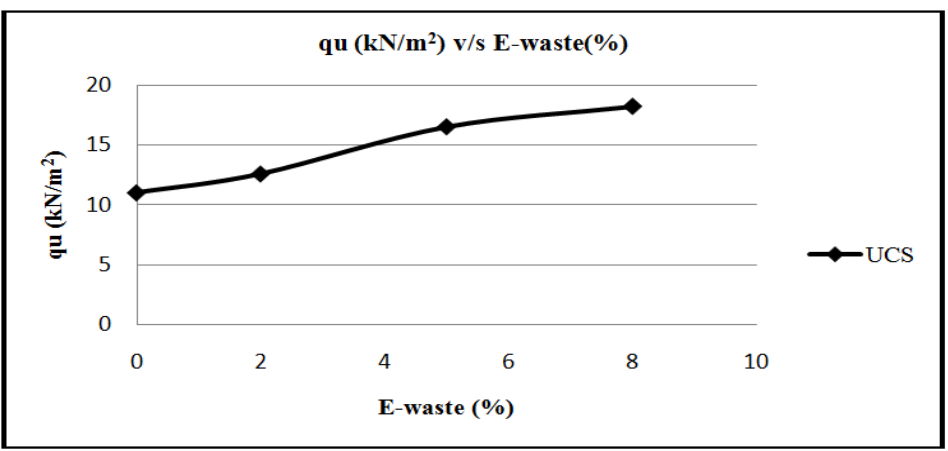

Fig 8: Variation of unconfined compressive strength with addition of E-waste 


\subsection{Direct Shear Test}

Direct shear test was performed for various samples of soil to determine the cohesion (C) and angle of internal friction $(\Phi)$.Variation in shear strength parameters can be observed in figure 9 with the addition of Ewaste.

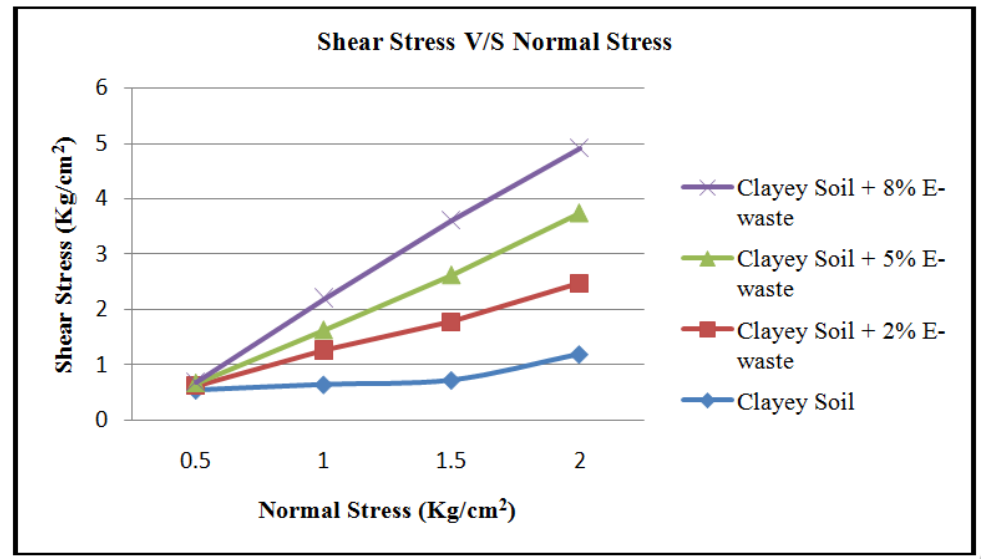

Fig 9: Variation in cohesion $(C)$ and angle of internal friction $(\Phi)$ with addition of E-waste.

From the figure 10 , it can be seen that the angle of internal friction $(\Phi)$ is directly proportional to percentage addition of E-waste

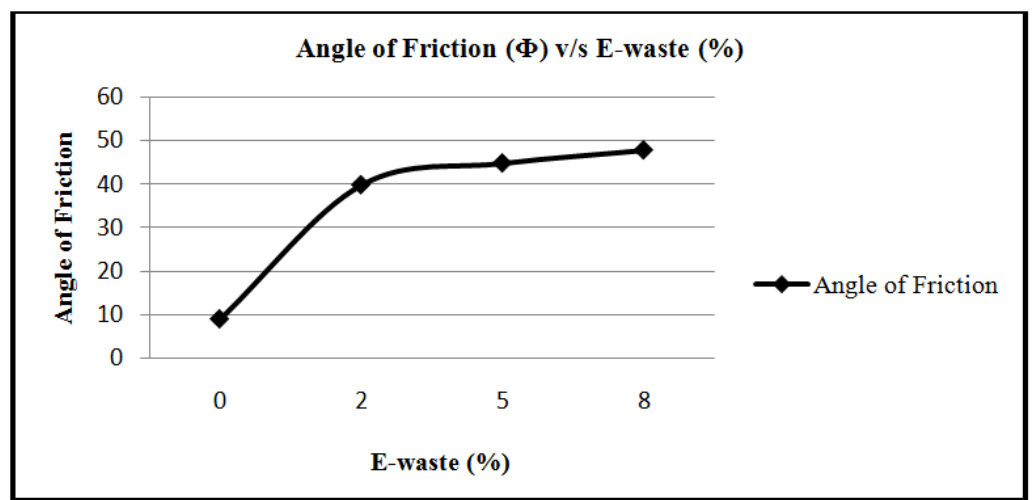

Fig 10: Variation of angle of friction with addition of E-waste.

\subsection{California Bearing Ratio (CBR)}

CBR value of the black cotton soil improves as the E-waste is added. Thus, objective regarding increase of CBR value is satisfied. Following figure shows the improvement of CBR value with respect to addition of E-waste. The variation in CBR value with addition of E-waste can be observed from figure 11.

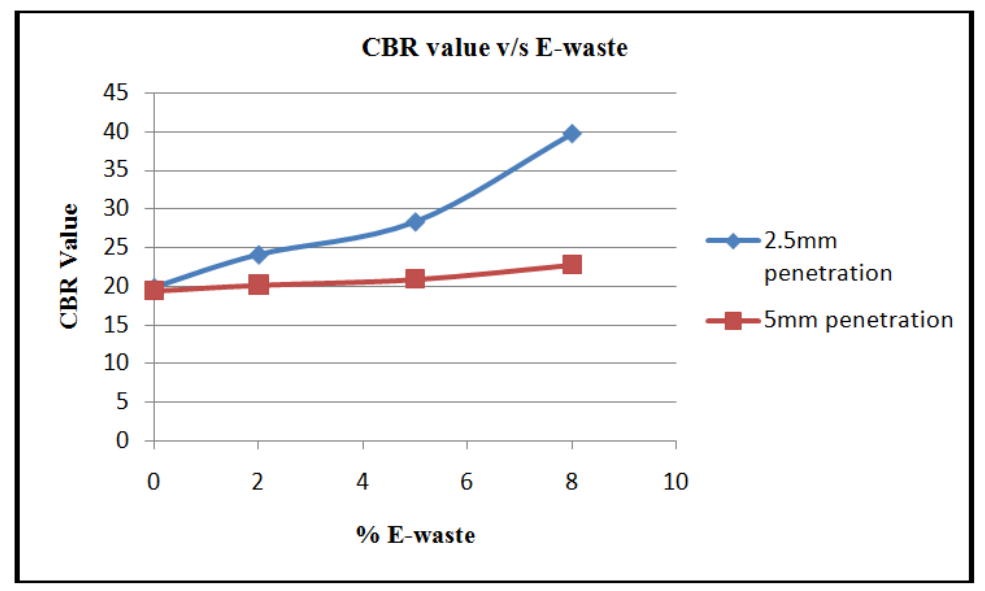

Fig No 11: Variation in CBR value with addition of E-waste. 


\subsection{Differential Free Swell Test}

As the addition of E-waste increases swell index decreases. Hence, low the swell index less will be the swelling of soil. Addition of E-waste thus reduces the swelling of the soil which is one of the good characteristic of soil.

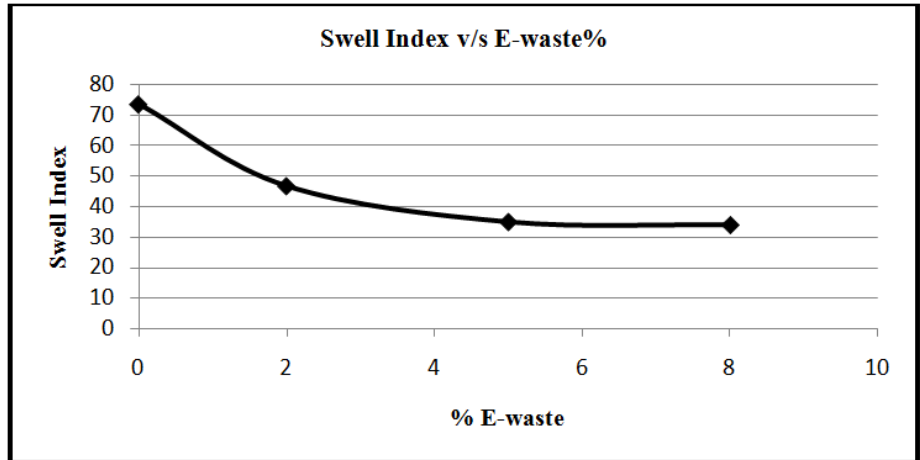

Fig No 12: Variation in swell index with addition of E-waste.

\section{Conclusions}

Based on the experimental work carried out in the present study the following conclusions are drawn for investigation of black cotton soil properties.

1. Specific gravity and liquid limit increased till 5\% addition of E-waste but decreased for $8 \%$ addition of Ewaste and plastic limit suddenly increased for 5\% addition of E-waste.

2. After performing direct shear test, there is an improvement in angle of internal friction $(\Phi)$ as the percentage of E-waste increases due to reduction in cohesion between soil and E-waste and increase in friction, as a result the bearing capacity of soil also increases.

3. The unconfined compressive strength of black cotton soil increased with an average $2.41 \mathrm{kN} / \mathrm{m}^{2}$ for fixed percentage of E-waste.

4. MDD increased and OMC decreased for $2 \%$ and $5 \%$ as the voids in the soil were filled by E-waste which results in dense soil. MDD gradually decreased for $8 \%$ dosage of E-waste.

5. The CBR value goes on increasing with respect to addition of E-waste.

6. It is observed that free swell index values of the soil have decreased with increase in E-waste.

\section{References}

[1] E.A. Basha a, R. Hashim a, H.B. Mahmud a, A.S. Muntohar, "Stabilization of residual soil with rice husk ash and cement", Construction and Building Materials 19, (2015), pp. 448-453.

[2] Kalumba D., Chebet F.C. "Utilisation of polyethylene (plastic) shopping bags waste for soil improvement in sandy soils".

[3] M.Adams Joe, A. Maria Rajesh, "Soil Stabilization Using Industrial Waste and Lime”, IJSRET, Vol. 4, Issue , July 2015

[4] Prakash Chavan, Dr. M. S. Nagakumar, "Studies on Soil Stabilization by using bagasse ash", IJSRET, ISSN: 2278-088, August, 2014

[5] Rahul Gupta, Anandkumar Raghuwanshi, "Utilization of E-waste in strength Enhancement of Black Cotton Soil", Mantech Publications, 2016

[6] S.G. Hambirao \& Dr.P.G. Rakaraddi), "Soil Stabilization Using Waste Shredded Rubber Tyre Chips", IOSR Journal of Mechanical and Civil Engineering, Vol.11 Issue 1, (Feb 2014)

[7] S.G. Hambirao \& Dr.P.G. Rakaraddi), "Soil Stabilization Using Waste Shredded Rubber Tyre Chips", IOSR Journal of Mechanical and Civil Engineering, Vol.11 Issue 1, (Feb 2014)

[8] Satish Sinha \& Dr.A. Mittal, "Impact of E Waste Recycling on Water \& Soil", 2014

[9] Satyam Tiwari, Nisheet Tiwari, "Soil Stabilization Using Waste Fiber Materials", IJITR Vol.4, Issue No. 3, 2016 